\title{
2
}

\section{A Commentary on the 50 -Year History of the University of the South Pacific}

\author{
Vijay Naidu
}

\section{Vijay Naidu: Personal Journey}

For the past four decades I have been an engaged Pacific scholar and, during this time, I have read and been influenced by the work of some pioneering scholars from The Australian National University (ANU), worked closely with ANU colleagues, and enjoyed longstanding friendships with several who were at ANU at some point in their working lives.

My undergraduate class of 1971 at the University of the South Pacific (USP) included Brij Lal and Kesaia Seniloli (both of whom later completed their PhD studies at ANU, and Brij would later become a distinguished professor at ANU), Rajesh Chandra (former vice chancellor of USP), and Justice Daniel Fatiaki (former chief justice of Fiji and currently judge of the Supreme Court in Vanuatu). Among our lecturers in subsequent years were Professor Ron Crocombe and Dr Ahmed Ali, both of whom had ANU connections. Studying Pacific history and societies, Pacific Islands development and migration, and ethnicity in Fiji meant that from my undergraduate days I was exposed to the scholarly writings of Jim Davidson, E.K. Fisk, Gerry Ward, Harold Brookfield, Ken Gillion, Neil Gunson, Deryck Scarr, Dorothy Shineberg and Oskar Spate. 
I worked closely with Professor Ron Crocombe as his tutor in the Advanced Pacific History course he taught at the third-year level. I owe my fortuitous entry into academia to him and Professor John Harre especially.

In addition to Brij Lal, other ANU scholars past and present with whom I have enjoyed friendship over the years, and/or whose work I have read and been influenced by, are Ahmed Ali, Stewart Firth, Greg Fry, William Sutherland, Ron Duncan, Ropate Qalo, Sandra Tarte, Scott MacWilliam, Stephanie Lawson, Katarina Teaiwa and Jon Fraenkel.

Research collaboration and attendance at seminars and conferences have resulted in a number of chapters in books published by ANU. David Hegarty, the former director of the State, Society and Governance in Melanesia program became a close associate and friend.

\section{Introduction}

The year 2018 marks the 50th anniversary year of the University of the South Pacific (USP) — a significant historic milestone and a proudly celebratory year. USP is one of two regional universities in the world, the other being the University of the West Indies (UWI). The notion of 'regional' has a specific meaning for these unique institutions as they are owned and financed by a number of small island states in a geographic region: the South Pacific for USP and the English-speaking Caribbean islands for UWI. Until 1991, USP had 11 member states. In that year, the Republic of Marshall Islands became the 12th member state and, with that milestone, the USP began serving the northern Pacific. Given the wide scatter of Pacific Island states in 'our sea of islands', the university serves a region spread over 33 million square kilometres of the Pacific Ocean. It is genuinely the University of Oceania. The significant and almost indispensable support of the United Kingdom, Australia and New Zealand, as well as other donor country assistance that USP has received since its birth in 1968, is acknowledged at the outset.

USP's 50th anniversary is worthy of the designated year-long celebration. It provides an opportunity for reflection on the institution's evolution, to flag its remarkable achievements and pay homage to those who have helped build it. It is also a time to think about contemporary issues and challenges that face the university and to peer into its future prospects and challenges in the coming decades. In the introduction of one of the 
commemoration books produced for the 25th anniversary of USP, the seminal A New Oceania: Rediscovering Our Sea of Islands, the then head of geography department, Professor Eric Waddell, remarked:

On this our 25th anniversary we need not only celebrate our past but reflect on our future; set, if necessary, a new agenda, revise our goals. Is this not the real mission of the School of Social and Economic Development: to contribute to the designing of a Pacific future? (Waddell, Naidu and Hau'ofa 1993)

The mission of contributing to the design of a Pacific future should, in fact, be one for the university as a whole.

\section{A Peace Dividend}

Today USP has 14 campuses and 10 centres, with three campuses in Fiji and a campus each on the remaining 11 member states. As will be shown, student numbers have increased several thousand fold. However, it all began on the grounds and buildings of the former Royal New Zealand Airforce (RNZAF) base in Laucala Bay in Suva. The end of the Pacific war, the last theatre of war in the Second World War, meant that New Zealand and its allies did not need the base anymore. The idea of a regional university in vogue at that time coincided with the availability of more than 70 hectares of undulating land from the coast to the crest of the Muanikau hills. The British colonial government of Fiji agreed to make the land and all its buildings and facilities, including the largest wooden aircraft hangar in the southern hemisphere and a swimming pool, available for the new university. This peace dividend became the site of the headquarters of the USP, the premier higher education centre for the region and the cradle of the regional anti-nuclear and independent Pacific movement, building the campaign against nuclear weapons testing in French Polynesia and, later, the nursery for independence and prodemocracy movements.

\section{Brief History}

The history of USP and some of its achievements in the first two-and-ahalf decades of its existence are well covered in the book Pacific Universities: Achievements, Problems, Prospects written by former staff of the university (Crocombe and Meleisea 1988), and the 25th anniversary publication 
A Garland of Achievement (USP 1993). The first substantive vice chancellor of the university, the late Dr Colin Aikman, who served USP from 1968 to 1974 , wrote in the latter book, 'We set out to turn a dilapidated flying boat base at Laucala Bay into the campus of a viable regional university', constructing university buildings and facilities in member countries. Dr Aikman justified USP's establishment on the grounds that students from the regional university would return to serve their countries upon graduation, and contribute to social and economic development. He went on to say:

Everywhere you look in the region USP graduates have prominent positions in government, in education and in other walks of life. There is, too, the USP 'mafia' - the USP graduates throughout the South Pacific who maintain valuable contacts with one another (Aikman 1993:5).

The university has been contributing to the creation and growth of a pan-Pacific identity through its students becoming more aware of the wider USP region, and that Oceania has shared histories and cultures as well as common challenges and possibilities. As noted by the late Professor Epeli Hau'ofa, there is considerable scope for enhancing both this supra-national identity and solidarity.

In his introduction to USP's 1999 Annual Report, the university's fifth vice chancellor and the first 'regional' person at the helm, Esekia Solofa succinctly summarised the university's growth:

The development of USP since its formal constitution by charter in 1970 saw the 70s decade as a period of building and establishment, followed in the eighties by a period of rationalization and consolidation. USP had come of age by the end of the eighties. It entered its third decade with youthful zest and confidence, ready to tackle the various challenges facing the development of its member countries and the region, through the provision of higher education. The nineties saw considerable expansion in the university as areas of study widened and new programmes were added; as support services were upgraded and new innovations introduced in their operation; as total enrolments grew, new buildings [were] constructed, and more staff recruited (Solofa 2000:1).

The first 19 years of the new millennium have seen the continued expansion of buildings and facilities on nearly all campuses and centres of the university, as well as a growth in student numbers in virtually all modes of undergraduate studies and in postgraduate enrolments. Of special significance is the Japan-Pacific Information and Communications Technology (ICT) Centre, which houses the university's ICT hub, and 
a large multipurpose lecture theatre as well as conference, IT labs and office facilities. Former vice chancellor Savenaca Siwatibau (2001-03) began the negotiations towards having this complex built. This edifice is an addition to previously built structures such as the library, the Japanesefunded Marine Studies complex on the 'lower campus' at Laucala, and the Australian-funded lecture theatres on the 'upper campus'. All these facilities, together with the three faculty buildings, enhance the university's modern outlook and complexity. Visiting USP alumni bringing their children to enrol have been heard to remark that they no longer recognise the campus because of this transformation.

New buildings and campus upgrades have been completed in regional campuses and centres, although progress has been uneven. Kiribati, Marshall Islands and Nauru have been the most recent sites of expanded facilities. A major new campus is planned for the Solomon Islands where the new School of Public Health will be located. The state of the present Honiara campus leaves much to be desired.

Noteworthy too are the efforts by the university to continuously upgrade its ICT facilities and the USPNet that links the campuses and centres. This is vital both for communication and exchange of data. Professor Rajesh Chandra, the former vice chancellor and president of USP, can be credited for his push to make the university's ICT facilities among the best in the South Pacific, and for the leap forward to online teaching and learning.

The university's development has not all been rosy. It has coped reasonably well with the demands of 12 member states, and their changing human resources needs, along with addressing difficult financial and resource constraints. External factors such as relative stagnant economies of member states, and in particular political instability and military coups in Fiji and the 'tensions' in the Solomon Islands, have affected the university. The Fiji coups of 1987, 2000 and 2006 have been especially disruptive as they increased the sense of insecurity among staff and students. The presence of armed soldiers of the Republic of Fiji Military Forces on Laucala campus, and the detention and torture of academics after the 1987 coups, traumatised the university community. In the Solomon Islands, the fighting in Guadalcanal and the overthrow of government in 2000 accompanied by lawlessness not only disrupted the lives of most Islanders but particularly affected schools and tertiary institutions, including USP's Honiara campus and the Institute of Marine Resources on Guadalcanal. 
The late Geoffrey Caston, USP's fourth vice chancellor (1983-92) stood steadfast in keeping the university open during the unprecedented period of instability in 1987 . He declared that the university was 'involved now in the defence of a bridgehead for our values' (Caston 1987:5) and, in the trying circumstances of military dictatorship, sought to keep alive academic freedom. His successor, Esekia Solofa (1992-2001), identified another significant role for the university. In 1993 he opened the first national dialogue in Fiji between political and civil society leaders to address the constitutional crisis in the country. The event was organised by the Citizens Constitutional Forum (CCF). He said the university campus should always be an open and 'safe space' to dialogue on matters of serious national importance for member countries (CCF 1993:1). The University Council considered whether to spread more of the university 'real estate' across other member countries to reduce the risks posed by political turmoil in any one country. There was talk about relocating the university headquarters from Fiji to another member state.

University staff and students were further traumatised by the ethnically motivated insurrection of May 2000 led by George Speight and his group against the Fiji Labour Party-led government of Mahendra Pal Chaudhry. Chaudhry and the government ministers and backbenchers were taken hostage for 56 days, during which time there were periods of 'mob rule' in parts of the country. Schools and the university opened and closed depending on rumours about gangs of rebels heading towards Suva's central business district or to the campus. Academic freedom was seriously compromised when the university administration decided to shut down the website of its journalism students' newspaper Wansolwara, which provided excellent coverage of the unfolding political instability and the military coup, on 29 May 2000 because of 'security reasons' (Robie 2000).

Following the December 2006 coup, the university became somewhat complicit in gagging academic staff from openly criticising government policies, and eventually compelled a leading economics professor to relinquish his position. The university also adopted a policy that sets out to restrict staff from communicating directly to the media. This restriction is accompanied by another prohibition that seriously compromises the governance of the university; staff have been prohibited from communicating with members of the University Council and its Chair 
if they have complaints and grievances that remain unresolved through normal university processes. Complaints about the vice chancellor and president need to be made to the vice chancellor and not to Council.

In short, even though USP continues to pay lip-service to its commitment of academic freedom, the political environment in Fiji has made the university not particularly enthusiastic about promoting healthy debates and discussions about Fiji politics, economy and government policies.

\section{USP Member States}

The 12 member states of USP are Cook Islands, Fiji, Kiribati, Marshall Islands, Nauru, Niue, Samoa, Solomon Islands, Tokelau, Tonga, Tuvalu and Vanuatu. As co-owners of the university, their representatives sit in the USP Council together with representatives of donor countries, university officials and academics. The council makes policy decisions as well as deciding matters relating to university finance, the appointment of the chancellor, pro-chancellor and vice chancellor. As in other universities that follow the British model, the chancellor is the symbolic head of the institution. The position is rotated each year among the heads of state of USP member countries. Up to the end of June 2018, the President of the Republic of Fiji was the Chancellor. The current Chancellor is the President of the Republic of Kiribati, Taneti Maamau.

The new chancellor, USP's 25th, is His Excellency Taneti Maamau, the President of the Republic of Kiribati. The pro-chancellor is elected by council and has the responsibility of chairing university council meetings. The vice chancellor and president (the nomenclature 'president' is a recent addition to the vice chancellor title) is the principal head of the university and is responsible for the daily operation of the institution. On completion of the eighth Vice Chancellor Professor Rajesh Chandra's term (2007-18), the position was filled by Professor Pal Ahluwalia who had previously been Pro-Vice Chancellor Research and Innovation at the University of Portsmouth in England.

Member states of the university contribute to its funding based on a formula that seeks to apportion financial subventions according to the benefits that accrue to each member state. As Fiji has the largest campus, it has most of the students, its citizens form the biggest pool of employees, it is the largest recipient of USP tax revenue, and it has historically been 
the largest contributor. Other sources of funding include student fees and donor contributions, both of which have increased significantly in recent years.

Like other Council of Regional Organisations in the Pacific (CROP) member agency boards, the USP Council has tended to rubber stamp the policies that the head of organisation and the senior management team have proposed. They also tend to listen and accede to advice by non-member state and donor country representatives. In recent years, this tendency has become more marked, and especially disturbing is the relative passivity of representatives of member states in contrast to the active role played by Australia and New Zealand representatives. As aid from the latter countries to the university has increased, there has been a parallel increase in how much say they have in the affairs of the university. Australia and New Zealand government representatives who have been university vice chancellors have sought to make USP in the image of their own universities. This approach has eroded the unique and special features of USP's regional and Pacific character (see Naidu 2004 for further discussion on seeking equality of partnership between aid donors and recipients citing USP as an example). The path taken by USP, like so many other universities, has been to focus on making and/ or saving money, becoming accredited or ranked, rather than fulfilling its educational objectives. Issues related to this trend will be addressed under some of the sub-headings below.

\section{USP's Reach as a Regional University}

As mentioned earlier, the member states of the university are spread over a huge expanse of the Pacific Ocean, posing daunting challenges of communication and transportation.

University campuses are located in each one of these countries' capitals, and in some instances there are university centres in the outer islandsas in the case of Vanuatu, which has four such centres. Besides Laucala campus, which has the university's three faculties-Faculty of Arts, Law and Education, Faculty of Business and Economics and Faculty of Science, Technology and Environment- there are two other large campuses. These are Alafua campus in Apia, Sāmoa, which is the home of the School of Agriculture and Food Technology and the Institute of Research, Extension 
and Training in Agriculture (IRETA); and the Emalus campus in Port Vila, Vanuatu, where the School of Law and the Pacific Languages Unit are located. Fiji hosts two other campuses in Lautoka and Labasa.

Almost from its very inception the university set out to be the higher education institution for the region by progressively establishing university centres for distance learning and teaching in all its member states. USP has been recognised as a world leader in the use of satellite communication (initially, the Pan-Pacific Education and Communication Experiments by Satellite program, or PEACESAT) in connecting these centres to Laucala campus. Over some three decades, distance and flexible learning was provided with the use of print materials and visits by mainly Suvabased tutors. Given the tyranny of distance and associated transportation of mail bags, the university overcame considerable challenges in the delivery and receipt of course materials, assignments, test papers and examination scripts.

Since the advent of computers and the internet, the university has adopted the use of online facilities for teaching and learning. Serious challenges do remain because of the relative paucity of privately owned computers, computer lab facilities and internet access or connectivity issues in some of the member states. In these countries there are also infrastructural limitations (such as bandwidth) and regulatory bottlenecks. Students in countries outside of Fiji struggle to access course materials and related resources. Online teaching of courses has increased staff workloads as many staff also teach the same courses face-to-face, and there are challenges regarding coordination of teaching and learning with numerous tutors and markers across member states. The availability of lecture slides on the internet has also meant that, in some courses, student attendance in faceto-face classes has significantly dropped.

\section{The University Library}

As in the case of regional centres and campuses, the university recognised from the beginning that having a good library was pivotal to learning, teaching and research. University librarians, Esther Williams, Sin Joan Yee and Elizabeth Reade-Fong and their staff, have been at the forefront of establishing a world-class library. The university library has grown in tandem with the university, with state of arts facilities and thousands of books and hundreds of journals. With the IT revolution, it has become 
the information hub for students, staff and the wider public alike. Library staff have also offered courses and programs of study in librarianship and related information technology. The main USP library has digitised collections and subscribes to search engines that allow wide access to scholarly journals. This library is also linked to and facilitates other libraries in the 15 campuses. The Pacific Islands Marine Resources Information System is based in the marine studies complex, but is part of a network of libraries and information centres of regional organisations and government departments involved in fisheries and marine resource work.

Besides the special collection of books, journals and writings on the Pacific in the Pacific Collection of the USP Library, the university also has the South Pacific Regional Herbarium and Biodiversity Centre, which has thousands of Fiji and Pacific plant materials in its care. The university's School of Law (Emalus campus, Port Vila) established the Pacific Islands Legal Information Institute (PacLII) so that students from across the region could have easier access to legal materials. It is now used by governments, non-government organisations, legal scholars and professionals, students and members of the public-and is seen as an example of excellence for providing legal information.

\section{Institutes and Centres}

The university has been changing its form and component structures together with some of its functions over the years. A good illustration of such changes is the creation and phasing out of institutes and centres. The flamboyant second vice chancellor of USP (1975-82) was Dr James Maraj, a Trinidadian and former head of the Commonwealth of Learning, who created a number of institutes and centres to enhance the university's research and consultancy activities. These were the Institute of Pacific Studies (IPS), the Institute of Applied Sciences (IAS), the Institute of Education (IOE), the Institute of Marine Resources (IMR), the Institute of Research, Extension and Training in Agriculture (IRETA) and the Institute of Social and Administrative Studies. These institutes were linked to the schools of the university. A Centre for Applied Studies in Development, a Centre for Appropriate Technology and Development and an Atoll Research Centre were also established, but none of the centres proved viable and were disbanded. Of the six institutes, only four have variously survived: the IAS, IMR, IOE and IRETA. The Pacific Institute of Advanced Studies in Development and Governance was 
also short-lived. The Pacific Centre for Environment and Sustainable Development (PaCE-SD), a relative newcomer, has become a dynamic hub of postgraduate research and advocacy on climate change, aided by a healthy boost of funding and a passionate director.

A major challenge to self-funded entities such as these centres and institutes has been the capacity of member state governments, businesses and civil society organisations to pay for services rendered. Generally speaking, international financial institutions and other multilateral agencies, including the UN system, have opted to use the services of Australian and New Zealand institutions and companies to do work in Pacific Island countries (PICs).

\section{USP Restructuring}

Among the variety of changes that the university has undergone are those that have strengthened its teaching and research capabilities and those that have detracted from these core functions. USP began 50 years ago with three interdisciplinary schools. While there were recognised disciplines, the objective was to promote interdisciplinary and multidisciplinary teaching and research. Ten years on from this orientation and thanks to senior academics who came from 'traditional universities', departments emerged with their own heads and the rise of separate silos. The schools continued to exist (two with name changes) and did try to encompass the earlier objective of cross-disciplinary work. This model existed until the new millennium. From the early 2000s, the schools were replaced by faculties: Arts, Law and Education; Business and Economics; and Science, Technology and Environment. Each of these faculties are led by a dean.

The Pacific Technical and Further Education (Pacific TAFE) has been recently added to provide vocational programs and has incorporated the university's pre-degree foundation programs.

A marked shift in the processes of decision-making and the relative size and influence of administrative units of the university has accompanied this restructure. Academic staff including professors have little say in policy decisions because the former school boards of study have been abolished and executive power resides in the office of deans and in the vice chancellor and president's office. The latter position has considerable power bestowed on it and, in many ways, the senior management team has 
become the main decision-making body of the university. The University Senate, the apex academic forum is a shadow of what it had been before the restructure. The trend has been towards top-down management.

The restructure also phased out the internationally renowned Institute of Pacific Studies (IPS), which published the largest number of works of Pacific Islanders and virtually on all Pacific Island countries, and the region as a whole. IPS was replaced by the poorly resourced USP Press.

\section{University Staff}

USP is home to the largest pool of well-qualified academics in the South Pacific Islands. In 1969 there were 31 academic staff, today there are over 300. In the very early years of the university, a majority of the senior staff including the vice chancellor, registrar and heads of schools and professors came from New Zealand. Very quickly, however, the mix of nationalities became more diverse with Australians, British, Americans (including Peace Corps volunteers, and former volunteers), Canadians, Indians, Cook Islanders, Fijians, iKiribati, Samoans and Tongans joining as academics and administrators. This mix was further enhanced with Solomon Islanders, Ni-Vans, Niueans, Tuvaluans, Africans and other nationalities. Indeed, it was noted at a conference in the mid-1990s in Melbourne on the internationalisation of education, that USP was only second to the University of Singapore in its openness to recruiting academics internationally. By this stage, the university comprised staff from more than 30 nationalities (Naidu 1997).

A major challenge for the university, however, has been the recruitment and retention of quality staff, both regional and foreign, male and female. USP emoluments have never been competitive with those offered in neighbouring Australia and New Zealand. With the adoption of more market-based policies and the removal of subsidies in housing and other support, the university has not been able to attract and retain good-quality mid-career academics, let alone those who are at the top of their career. Various incentives and inducements have generally failed to entice staff for the long haul, especially from Australia, New Zealand and United Kingdom. There has been an increasing reliance on shorter term appointments of retired expatriate professors, and academics from South Asia. 
With some exceptions, even well-qualified regional staff from USP member states have not continued their employment with the university. The reasons for this lack of stability in staffing according to Sarojini Pillay, a former registrar, have been 'insecurity inherent in a contract system, national immigration policies, high taxation, lack of competitiveness of USP salaries with those overseas and few employment opportunities for spouses'(1993:92). The longstanding three-year contracts did not help either. Although Fijis direct personal taxation is now below the international average, USP's emoluments remain uncompetitive, and there are extremely limited opportunities for spouses of expatriate staff to be gainfully employed.

The university has recently moved towards offering five-year contracts to a few selected academic staff, but it has continued to refuse to institute tenure, despite tenure being a standard practice in comparative universities that USP benchmarks itself against. It is unsurprising, given USP terms and conditions of employment, that academic staff numbers have declined in recent years whilst student numbers have increased. In 2016 there were 425 academic staff but in 2017 , that number had declined to 332 staff (USP 2017:22). It is also of concern that fewer quality appointments are being made at the professorial and associate professorial levels. Senior academic staff (senior lecturers, associate professors and professors), as a proportion of the staff establishment, have decreased from the envisaged 40 per cent to 35 per cent; tutors, teaching assistants, assistant lecturers and lecturers now predominate (statistics derived from USP annual reports up to 2017 and earlier staff policy documents). USP's current staff-student ratios are largely at variance with internationally accepted ratios for quality teaching and learning.

Meanwhile, USP's glossy annual reports have been winning prizes for corporate annual reports.

\section{Students: A Home Away from Home and a Place of Diversity}

The university began with a little over 150 students mainly in preuniversity level, Preliminary 1 (form 6 equivalent) and Preliminary 2 (form 7 equivalent) programs. In 1969, of the 249 students, only 12 per cent were in degree studies, but by 1974 the situation had changed with almost 37 per cent of the 981 students undertaking degree studies, 
and a further 36 per cent enrolled in Diploma in Education programs (Aikman 1988:41). By 1993, student numbers had increased to 8,000, and by 1999 to a little more than 10,000. In 2017, the number was close to 30,000 with almost equal numbers studying in the face-to-face mode as in distant and flexible modes.

The students are mainly from member countries with Fijian students comprising over 70 per cent and other country student numbers reflecting their relative population size. The Solomon Islands, for instance, has the next highest number. Diversity is the hallmark of the student body. To begin with, students from the member states represent the geographical and supposed cultural regions of Melanesia, Polynesia and Micronesia, and bring with them considerable cultural diversity. However Solomon Islander, ni-Vanuatu and Fijian students are the most culturally diverse. The cosmopolitan nature of the larger campuses are added to by international students from Australia, New Zealand, Canada, the United States of America, Europe, China, India, Japan, Korea and African countries, as well as countries of the Caribbean region such as Barbados, Belize, Guyana, Jamaica and Trinidad, who come under exchange schemes. International students make up less than 5 per cent of the USP student body.

There is relative gender parity in student numbers, and in recent years there have been more women graduates than men. Women are also taking up studies in those disciplines that have long been dominated by men, such as engineering and physics. Students have generally got on well and in the larger campuses of Laucala, Alafua and Emalus, regional students feel at home because of similarities in cultures and the relationships that they have with each other and with staff members.

Over the last five decades, the university has produced more than 50,000 graduates and certificate and diploma holders. It has also trained hundreds of Islanders in shorter training programs to build capacity in the public services of member states. Among its graduates, the university can count presidents and prime ministers of PICs, members of parliament, ministers of state, diplomats, senior public servants, teachers, lawyers, engineers, economists and social scientists, chemists, biologists, accountants, medical doctors, physicists and energy experts, regional and international bureaucrats, academics and researchers. In virtually every regional organisation and forum, it is inevitable these days to come into contact with USP alumni. 
Having contributed enormously to the human resource needs of member states from the 1990s onwards, the university began to pay increasing attention to postgraduate programs of study and research degrees. It also sought to enhance its profile as a centre of research excellence in all aspects of the Pacific. Postgraduate diplomas, course work-based masters qualifications as well as research degrees at the masters and doctoral levels have emerged over the last three decades. These are both disciplinebased (for example, MSc in Chemistry, MA in Education and MCom in Economics) and interdisciplinary. These latter programs of study include development studies, environmental studies, marine studies, tourism studies, and Pacific studies. The Graduate School of Business has been offering diplomas and the MBA degree in business-related specialisms. There are more than 1,000 successfully completed masters and doctoral dissertations (932 masters and $92 \mathrm{PhDs}$ ) in the university library's care.

While the spirit of volunteerism appears to have died among the elected officials of the USP Student Association, who pay themselves fortnightly stipends and sitting allowances for every council and committee meetings they attend, other students volunteer their services for charitable causes and for humanitarian relief and rehabilitation work after natural disasters. The long history and shared experiences of such volunteer efforts provide another basis for solidarity and the formation of an Oceanic identity.

\section{Remembering the Ancestors}

At every commemorative event in Oceania, the ancestors are acknowledged and homage is paid to them. Scores of staff-from those holding academic leadership positions to those responsible for secretarial support, maintaining the grounds of campuses and the cleaning and maintenance of facilities-have helped the university thrive. A good number have passed on. It is impossible to name all the people who have made USP prosper, but a few more prominent persons can be mentioned beginning with those at the helm. Former vice chancellors Colin Aikman, James Maraj, Frank Brosnahan and Savenaca Siwatibau who started the building of the university and contributed immensely to its growth have passed away but their legacies remain. For example, the negotiations for the construction of the Japan-Pacific ICT centre began with Mr Siwatibau. 
Vice chancellors Esekia Solofa and Rajesh Chandra have also overseen the consolidation and further expansion of the university. Among academics, the late Dr Ahmed Ali, Dr Uday Raj, Dr Alfred Liligeto, Dr Ajit Singh, Dr Prem Prasad, Dr William Kenchington, Professor Ron Crocombe, Professor Epeli Hau'ofa, Professor William Clark, Mr Tony Chappell, Mr Simione Durutalo, Dr Sadaquat Ali, Dr Michael Davis, Mr Lionel Gibson, Mr Kisor Chetty, Mrs Barbara Hau'ofa, Professor Asesela Ravuvu, Professor Bob Hughes, Professor Bob Briscoe, Professor Michael White and Professor William Aalbersberg taught and supervised generations of students and enhanced the reputation of the university through their research, writing and leadership. Their remarkable achievements have been paralleled by those of Professors Albert Wendt, Wadan Narsey, Patrick Nunn, Subramani, Subramaniam Sootheswaran, Konaiholeva Thaman and Randy Thaman.

To the list of distinguished scholars could be added the names of Professors Eric Waddell, John Morrison and Stewart Firth, as well as Dr Claire Slatter. Professor Crosbie (Croz) Walsh has been a dynamic teacher and researcher who inspired several cohorts of students in geography and development studies. Professor John Harre, who continues to be active in higher education circles, was known as a brilliant teacher and someone who inspired so many students to do well in their studies. The late Dr June Cook who specialised in European history inspired Professor Brij Lal to take up history and to become the most prominent scholar among the graduates of the university. Now retired from The Australian National University (ANU), Brij Lal has distinguished himself as a leading Pacific historian.

Other scholars and administrators who have contributed in their disciplinary and specialist areas of work include Dr Howard van Trease, Dr Clare Mathewson, Dr Richard Wah, Dr William Sutherland, Dr Surend Prasad, Associate Professor Greg Fry, Professor Biman Prasad, Professor Don Patterson, Marjorie Crocombe, Professor John Lynch, Professor David Harrison, Professor Robbie Robertson, Professor Robin South, Professor Nii-K Plange, Dr Kesaia Seniloli, Dr Martin Baker, Dr Ganesh Chand, Pio Manoa, Philip Rama, Sarojini Pillay, Seona Smiles, Dr Gunu Pillai, Professor Srinivasiah Muralidhar, Sundari Muralidhar, Paddy O'Sullivan, Filimoni Fifita, Lilly Vesikula, Tito Isala, Walter Frazer, Mela Vusoniwailala, Lillian May, Lillian Bing, Associate Professor Morgan Tuimaleali'ifano, Eileen Tuimaleali'ifano, Associate Professor Joeli Veitayaki, Professor Malama Meleisea and Professor Penelope Schoffel. 


\section{A Beautiful Cemetery}

In A Garland of Achievement, Professor Epeli Hau'ofa, who led the Department of Sociology and the School of Social and Economic Development and then became the founder and iconic Director of the Oceania Centre for Arts and Culture, referred to the university's Laucala campus as a 'beautiful cemetery'. He said, 'The university is a beautiful cemetery-an intellectual cemetery. There is nothing on culture and the larger issues about where we are going' (1993:81-82). This perception emerged from his observation of the sharp contrast of Laucala campus before the 1987 coup and following the coup. Before the military overthrow of the month-long Fiji Labour Party Government led by Dr Timoci Bavadra, the campus had been a reflection of the changes taking place in the region as countries gained their independence. There was cultural ferment reflected in creative writing of poetry and plays, as well as other writing that related to 'our identity and to important social and political issues' (ibid.).

The post-coup interim government's free market system orientation and the end of the cold war had serious consequences for the university:

Other things, like training for management and computing and accounting were even more emphasized. I think that had more damaging effect on intellectualism ... than the coup itself ... Talking about larger issues of social concern became of little value (ibid.).

There is much truth in what Epeli Hau'ofa observed regarding intellectual life of the university before and after 1987. In one sense, USP's redirection to business studies and computing was a response to the human resource demands of member countries in the throes of globalisation-the coup and its 'free market' aftermath possibly expedited the process.

While the Laucala campus has not returned to the cultural ferment of USP's first 20 years, a number of sparks of intellectual and cultural life have reemerged. Generally, public lectures and seminars on all kinds of subjects are being held almost on a daily basis in the schools and faculties on Laucala campus. Particular entities and schools have been especially active, including the now-named Oceania Centre for Arts, Culture and Pacific Studies. This centre has continued Hau'ofa's legacy of keeping an open door for people to show and enhance their potential as artists without any formal academic training or accreditation. The teaching of Pacific cultures and societies continues in Pacific Studies, and the centre 
has gained renown for its visual, music and performing arts, which combine Pacific cultural themes with modern designs, choreography and rhythms. Hau'ofa had himself sought new forms of creativity and fusion of old and new.

USP has also introduced four general courses that are compulsory for all undergraduate students. Two of these courses seek to inculcate language, research and computer literacy. More significantly, two other courses introduce wider social and political issues that Hau'ofa was so dismayed were no longer being addressed. At the second-year level, these courses cover cultural, historical, environmental, social and political changes in Pacific Island countries and the region, as well as ethics and governance more broadly. The latter courses are designed to generate greater awareness among all students about Pacific issues and the importance of ethics in all aspects of their lives. In the Schools of Social Sciences and Government, Development and International Affairs, teaching and learning as well as research and outreach are centred on political, economic, social and psychological issues in Oceania and more globally.

Since the 1990s, environmental changes have become much more significant with atoll states facing existentialist threats from rising sea levels, and all countries of the region increasingly subject to extreme weather events. PaCE-SD has been playing a leading role in postgraduate training, research and advocacy relating to climate change. This vanguard role has also seen the birth of 'Pacific Climate Warriors 350' formed by, among others, graduates of PaCE-SD. The Schools of Marine Studies and Geography, Earth Science and Environment have also taken up the challenge to teach and research on marine resource management, oceanic changes, terrestrial resources and environmental concerns.

The School of Language, Arts and Media has been active in not only teaching literature and language, but also producing a range of creative writing including poetry and short stories. The media component of the school continues to teach crucially important journalism courses. Journalism students continue to practice their knowledge and skills in the production of their newspaper Wansolwara, which addresses topical matters inside and outside the university.

The Faculty of Science, Technology and Environment has actively researched renewable energy, including a 'wave solar energy harvesting device', wind turbine engineering and a mobile cane for blind and visually impaired persons, with patents registered for the energy-harvesting device 
and the mobile cane. At the School of Agriculture and Food Technology, experiments in more climate-resilient crops and livestock breeds have been undertaken with some positive results.

While the student body as a whole has been fairly dormant for several years and has continuing governance issues, the Marshall Islands Students Association (MISA) has in the last few years taken up the cudgels for environmental and social justice for their country, Micronesia and Oceania as a whole because of the ongoing effects of radioactive fallout from nuclear weapons testing by the United States. MISA has rekindled awareness and interest in the nuclear tests and their consequences for health and other impacts, as well as the 'dome' on Runit Island where, as sea levels rise, the release of radioactive materials into the sea will have an impact on the Pacific Ocean.

Social and political justice is also sought by some staff and students for West Papua. Human rights violations by Indonesia security forces are monitored and shared via social media. Periodic talks and updates are held on the struggle for self-determination in that occupied country, with visiting West Papuans providing the most recent information regarding the experiences of the indigenous people there.

The courage of a handful of individual academics to speak up on social and political issues during periods of media censorship and other restrictions should also be acknowledged. They have maintained the longstanding ethos of any self-respecting university as the critic and conscience of society. Epeli Hau'ofa would have been proud of them as they challenge his perception that Laucala campus had become a beautiful cemetery.

\section{The Future}

In his message on the silver jubilee of the university, the then vice chancellor Esekia Solofa acknowledged and honoured the achievement and contributions of staff and students, and said among other things that:

The University's role is essentially to assist in the development of its member countries. To do that properly, the University as a matter of necessity must have their support ... The next 25 years will see the demands of the region and the needs of the communities grow in complexity and sophistication. Many problems that now exist will remain, and there will be new obstacles and barriers to overcome. The University will need to be more dynamic, 
innovative and creative in its responses. The successes of the past could not have been possible without the active support of member countries. The future should not be any different (Solofa 1993:3-4).

However, the support of the member states of the university in the coming 25 years is not so assured by what has transpired in some member states, and globally in recent times.

\section{New Universities}

Fifty years ago there was no university in USP member countries (the University of Papua New Guinea was established in 1965) and USP upon its establishment in 1968 became the very first such institution for its 12 owning states, and the second such institution for all of Oceania, south of the equator. As universities are often seen as national symbols (like the national flag and airline), three member states have established their own universities in the last 25 years: the National University of Samoa, Fiji National University and Solomon Islands National University. These universities have become the priority consideration for their respective governments and it is likely that over time the support for the regional university may decline when it comes to tough decisions about funding. Indeed, in recent years, the funding from member states to USP has been relatively stagnant when compared to revenue raised in student fees, donor country contributions and other sources of income.

While the support of USP member states will remain crucial, the university has been compelled to seek alternative and complementary revenue streams. This has been most challenging given that per-capita income of member states together on average is still below US\$5,000. Student fees have been regularly raised and with the emergence of the new universities (in Fiji there are four universities now), the question of fees is increasingly competitive. Some revenue is generated from commissioned research and consultancies. This area has potential for further growth but competitors for commissioned research and consultancy work come from better resourced Pacific-rim countries, particularly Australia and New Zealand. The Pacific TAFE appears to be doing well in providing vocational certificates and diplomas at the pre-degree level. USP can also seek to become the regional higher education centre of excellence in postgraduate teaching and research. This will be in accord with its efforts to promote a research culture in the institution. 
Australia and New Zealand have been the largest donors and source of support for the university. Their funding support to USP has increased over time and, in recent years, there has been a greater reliance on aid funds for recurrent expenditure. As mentioned earlier, both Australia and New Zealand have representatives in the University Council, and they have become increasingly influential in the affairs of the institution. This trend has affected to some extent the ethos of USP. Instead of promoting Pacific values, epistemologies and ontologies, there has been a tendency to become like any other internationally recognised university desperately trying to get into the international university league table. A side effect of this trend has been a pronounced disdain for publishing its own books and journals that seek to serve member states and promote not only Pacific cultures and values, but also Pacific interests. This attitude must change if the unique character of USP is to be maintained and enhanced.

Besides budgetary issues, the other major and related challenge is the recruitment and retention of quality staff. Without attractive terms and conditions that will draw good academics to USP and make them want to stay for more than one contract, the university's future as a quality institution will be bleak. Very positively, after almost 50 years of employing academics on three-year contracts, the university is at last moving to five-year contracts. However, there is still no tenure track. The university has also abandoned its formerly effective staff development program of sending especially bright young staff for $\mathrm{PhD}$ studies abroad, often relying on scholarships and fellowships provided by donor countries and international organisations such as the Commonwealth. Today most young staff at the university struggle to complete their postgraduate studies as they carry disproportionately heavy teaching and marking loads. Additional extra workload comes from vacancies at senior levels remaining unfilled for long periods. This is most ironic because a good number of the senior regional academics at USP only obtained their PhDs through its staff development program.

\section{Conclusion}

Universities are expensive entities to establish and operate successfully. Over the last 50 years, a set of favourable circumstances beginning with the peace dividend of the former RNZAF base, member state support, donor funding, growing student numbers and dedicated staff have made USP a successful institution and an asset of the people and governments 
of Oceania. The university has been on top of its game by being a regional university of and for Oceania and by responding creatively to the changing demands in higher education and research in the region. It has had a long head start compared to its national-based counterparts, and has an incomparably superior reputation, at the heart of which are the achievements of its academic staff and students. The restructure of the institution has had negative consequences for academic staff who carry out the primary functions of teaching and research, but decision-making processes can be reviewed and corrected.

However, two longstanding hurdles will continue to affect USP: its funding and its capacity to recruit and retain quality staff. The major challenge for the university at this point in its history is to closely reexamine its core business of teaching and learning, research and community outreach in the context of Pacific realities, needs and interests.

\section{References}

Aikman, C. 1988. Establishment 1968-74. In Crocombe, R and M. Meleisea (eds), Pacific Universities: Achievements, Problems, Prospects. Suva: Institute of Pacific Studies, University of the South Pacific, 35-52.

Aikman, C. 1993. Of Bricks and Mortar. In A Garland of Achievement: 25 Years of Learning and Serving Together. The University of the South Pacific 1968-1993. Suva: University of the South Pacific, 5-6.

Caston, G. 1987. Address to Students and Staff of the University of the South Pacific, Suva, 30 June (in author's possession).

Caston, G. 1988. Consolidation. In Crocombe, R. and M. Meleisea (eds), Pacific Universities: Achievements, Problems, Prospects. Suva: Institute of Pacific Studies, University of the South Pacific, 75-96.

Citizens Constitutional Forum (CCF) 1993. The Vice Chancellor's Address. In Report of a Consultation on the National Agenda, 17-18 December. Suva: School of Social and Economic Development, University of the South Pacific.

Crocombe R. and M. Meleisea (eds) 1988. Pacific Universities: Achievements, Problems, Prospects. Suva: Institute of Pacific Studies, University of the South Pacific.

Hau'ofa, E. 1993. A Beautiful Cemetery. In A Garland of Achievement: 25 Years of Learning and Serving Together. The University of the South Pacific 1968-1993. Suva: University of the South Pacific, 81-82. 
Naidu, V. 1997. Internationalization of Higher Education in the South Pacific. In J. Knight and H. deWit (eds), Internationalisation of Higher Education in Asia Pacific Countries. Amsterdam: European Association for International Education, IDP Australia and the Programme on Institutional Management in Higher Education of the OECD, 147-60.

Naidu, V. 2004. Aid in the Pacific: What Works and Why? Development Bulletin No. 66 (September). Development Studies Network. Canberra: Research School of Social Sciences, The Australian National University, 117-24.

Pillay, S. 1993. Staff and Staffing. In A Garland of Achievement: 25 Years of Learning and Serving Together. The University of the South Pacific 1968-1993. Suva: University of the South Pacific, 92-94.

Robie, D. 2000. Pacific Journalism Online Website Censored. Pacific Media Watch - Pacific Nius. Scoop, 2 June. www.scoop.co.nz/stories/WO0006/ S00012/pacific-journalism-online-website-censored.htm

Solofa, E. 1993. A Strength of Will. In A Garland of Achievement: 25 Years of Learning and Serving Together. The University of the South Pacific 19681993. Suva: University of the South Pacific, 3-4.

Solofa, E. 2000. Introduction. The University of the South Pacific 1999 Annual Report. Suva: University of the South Pacific.

University of the South Pacific (USP) 1993. A Garland of Achievement: 25 Years of Learning and Serving Together. The University of the South Pacific 1968-1993. Suva: University of the South Pacific.

University of the South Pacific (USP) 2006-2017. Annual Reports. Suva: University of the South Pacific. www.usp.ac.fj/index.php?id=archivepublications

Waddell, E., V. Naidu and E. Hau'ofa (eds) 1993. A New Oceania: Rediscovering Our Sea of Islands. Suva: University of the South Pacific with Beake House. 
This text is taken from Understanding Oceania: Celebrating the University of the South Pacific and its collaboration with The Australian National University, edited by Stewart Firth and Vijay Naidu, published 2019 by ANU Press, The Australian National University, Canberra, Australia.

doi.org/10.22459/UO.2019.02 